\title{
An immunobioluminescence assay for gamma-gamma enolase activity in human serum and cerebrospinal fluid
}

\author{
R.A. Wevers ${ }^{\text {a }}$, A.W.G. Theunisse ${ }^{a}$ and G. Rijksen ${ }^{\text {b }}$ \\ ${ }^{a}$ Institute of Neurology, University Hospital Nijmegen, Nijmegen and ${ }^{b}$ Department of Haematology, \\ Laboratory of Medical Enzymology, University Hospital Utrecht (The Netherlands)
}

(Received 30 October 1986; revision received 22 July 1988; accepted after revision 12 August 1988)

Key words: gamma-gamma Enolase; Bioluminescence; Neuron specific enolase; Cerebrospinal fluid

\section{Summary}

A solid phase immunobioluminescence assay for the measurement of gammagamma enolase activity in human serum and cerebrospinal fluid is described. The assay combines the specificity of the antiserum with the specificity of measuring enolase activity, thus making the assay highly specific for gamma-gamma enolase. The sensitivity of the method allows determinations in unconcentrated cerebrospinal fluid samples. The new immunobioluminescence assay has been compared with a radioimmunoassay method. The correlation is good both for serum and CSF samples. However, different correlation lines are found for serum and CSF.

\section{Introduction}

The glycolytic enzyme enolase (2-phospho-D-glycerate hydrolase; EC 4.2.1.11) occurs in man as dimeric isoenzymes. Three different subunits, alpha, beta and gamma are found, only alpha and gamma being synthesised in the brain. The homodimeric isoenzymes can be regarded as markers of two major cell types in this tissue. The gamma-gamma isoenzyme is only found in neurons and neuronal tissue like the neuroendocrine 'APUD' cells (amine precursor uptake and decarboxylation) and peripheral neurons [1] and is therefore called neuron-specific enolase (NSE) [2], whereas the alpha-alpha form is situated in glial cells (non-neuronal enolase, NNE).

Correspondence to: R.A. Wevers, Institute of Neurology, University Hospital Nijmegen, Reinier Postlaan 4, $6500 \mathrm{HB}$ Nijmegen, The Netherlands. 
When brain tissue is damaged cytosolic enzymes leak into the cerebrospinal fluid (CSF) or into the blood. Therefore, raised gamma-gamma enolase levels in CSF have been demonstrated in patients suffering from cerebrovascular accidents [3], transient cerebral ischaemic attacks [3] and from comas resulting from anoxemia or head injury [4,5]. On the other hand, meningitis which preserves neuronal tissue, showed no change in NSE levels [4]. The gamma-gamma isoenzyme in plasma is also important in the diagnosis of tumours originating from APUD-cells, like neuroblastoma, melanoma, retinoblastoma, small cell carcinoma of the lung and certain carcinomas of the thyroid, the pancreas and the gut, although the specificity for these tumours is in discussion in the literature [6-12].

Enzyme-immunoassays $[4,13]$ and radioimmunoassays $[3,5,11,12,14]$ have been employed to measure gamma-gamma enolase. Gerbitz was the first to use a bioluminescence technique for the measurement of NSE in human plasma [15]. Recently, Viallard et al described a bioluminescence assay for NSE in serum using differential immunocapture measuring NSE activity by subtracting alpha-alpha activity from total enolase activity [16]. The assay described in this paper uses an antibody against gamma-gamma enolase, attached to a solid phase immunobead to absorb specifically the gamma-gamma isoenzyme. The activity of bound gammagamma enolase is determined directly on the immunobeads by means of a bioluminescence assay [17]. This has the advantage over the method described by Viallard that only one determination is required to obtain the result. Whereas EIA and RIA methods measure gamma-gamma enolase antigen quantities, the immunobioluminescence assay quantifies gamma-gamma enolase enzymatic activity in the sample. The assay combines the specificity of the antibody with the specificity of measuring the enzymatic activity of the enzyme. To our knowledge this is the first report measuring gamma-gamma enolase enzymatic activity in cerebrospinal fluid.

\section{Materials and methods}

\section{Patient samples}

Enolase isoenzymes were partially purified from human autopsy material as described previously $[17,18]$. CSF samples used in this study were from neurological patients. The samples were sent in from the neurological wards of the hospital without a special request for enolase measurement. The CSF samples had normal cell counts, protein and pigment levels. They were selected from the daily routine requests of the laboratory without any prior knowledge of the clinical background of the request. Serum samples were from healthy volunteers. Both CSF and serum samples were measured within $24 \mathrm{~h}$ of collection. Till measurement they were stored at $4{ }^{\circ} \mathrm{C}$. After measuring they were kept at $-70^{\circ} \mathrm{C}$ for a RIA test.

\section{Preparation of antibodies}

Antibodies against human gamma-gamma enolase were raised in sheep as described before [18]. The crude antiserum appeared to be specific for gamma-enolase subunits. It was purified by precipitation with a partial purified NSE preparation from human brain, obtained after DEAE-A50 chromatography [18]. After centrifu- 
gation for $20 \mathrm{~min}$ at $48000 \times \mathrm{g}$, the antigen-antibody complex was dissociated in glycine-citric acid buffer $(0.133 \mathrm{~mol} / 1$ glycine, $0.104 \mathrm{~mol} / 1$ citric acid, $0.514 \mathrm{~mol} / \mathrm{l}$ $\mathrm{NaCl}$ ) and the components were separated by gel filtration on a S-200 column (Pharmacia, Sweden) in the same buffer. After gel filtration, the IgG preparation was dialyzed against phosphate buffered saline containing $0.2 \% \mathrm{NaN}_{3}$. One $\mathrm{mg}$ of purified IgG was able to precipitate $1 \mathrm{U}$ of gamma-gamma enolase activity (defined as the amount of enzyme converting $1 \mu \mathrm{mol}$ substrate $/ \mathrm{min}$ at $37^{\circ} \mathrm{C}$ ), which is equivalent with $20 \mu \mathrm{g}$ of gamma-gamma enolase protein, assuming a specific activity of $50 \mathrm{U} / \mathrm{mg}$ protein for brain enolase (data calculated from Taylor et al [19]).

\section{Preparation and reuse of the immunobead reagent}

2-2.5 mg purified antiserum was required for $50 \mathrm{mg}$ ( $5 \mathrm{ml}$ suspension) immunobeads (Bio-Rad Immunobead Reagent Catalog No. 170-5910, Richmond, CA, USA). The antibody was dialyzed for $18 \mathrm{~h}$ at $4{ }^{\circ} \mathrm{C}$ against the coupling buffer $(0.003$ mol/1 $\mathrm{KH}_{2} \mathrm{PO}_{4} / \mathrm{KOH}, \mathrm{pH} 6.3$ ). The immunobead suspension was centrifuged (10 min, $1000 \times g 4^{\circ} \mathrm{C}$ ) and decanted prior to addition of antibody. After addition of antibody the total volume was adjusted to $5 \mathrm{ml}$ with the coupling buffer. This reaction mixture was incubated at $4^{\circ} \mathrm{C}$ for $1 \mathrm{~h}$. Then $10 \mathrm{mg}$ EDAC (1-ethyl-3(3-dimethylaminopropyl)carbodiimide $\mathrm{HCl} /$ Biorad 170-5910) was added. The $\mathrm{pH}$ was maintained at 6.3 for $30 \mathrm{~min}$ and the reaction mixture was stored overnight at $4^{\circ} \mathrm{C}$. Subsequently the immunobeads were washed to remove non-covalently hound material. In every washstep $20 \mathrm{ml}$ of wash volume was required, while the mixture was centrifuged for at least $10 \mathrm{~min}$ at $1000 \times \mathrm{g}$. Successive washsteps were respectively three times with PBS $\left(0.01 \mathrm{~mol} / 1 \mathrm{KH}_{2} \mathrm{PO}_{4} / \mathrm{KOH}, 0.15 \mathrm{~mol} / 1 \mathrm{NaCl}, \mathrm{pH} 7.2\right)$, three times with $1.4 \mathrm{~mol} / 1 \mathrm{NaCl} / \mathrm{PBS}\left(0.01 \mathrm{~mol} / 1 \mathrm{KH}_{2} \mathrm{PO}_{4} / \mathrm{KOH}, 1.4 \mathrm{~mol} / 1 \mathrm{NaCl}\right.$, $\mathrm{pH}$ 7.2) and twice with PBS.

After this procedure the immunobead reagent was resuspended in $20 \mathrm{ml}$ PBS and stored at $4^{\circ} \mathrm{C}$ for at least $3 \mathrm{~h}$ to allow complete renaturation of bound antibody. To avoid nonspecific adsorption the reagent was adsorhed with $\mathrm{BSA}$ by two washes with $0.005 \mathrm{~mol} / 1 \mathrm{KH}_{2} \mathrm{PO}_{4} / \mathrm{KOH}(\mathrm{pH} 7.2$ ) followed by resuspension in $5 \mathrm{ml} 0.005$ mol $/ 1 \mathrm{KH}_{2} \mathrm{PO}_{4}, / \mathrm{KOH} / 10 \mathrm{~g} / 1 \mathrm{BSA}$. The immunobead reagent was stored in this buffer at $4^{\circ} \mathrm{C}$. Four months after preparation the immunobead reagent showed no loss of binding capacity.

The used immunobead reagent may be reused several times. Therefore the collected beads were washed with $2 \mathrm{~mol} / \mathrm{l}$ potassium thiocyanate for $1.5 \mathrm{~h}$ at room temperature. After centrifugation ( $10 \mathrm{~min}, 1000 \times \mathrm{g}$, room temperature), the pellet was washed twice with $10 \mathrm{~g} / 1 \mathrm{BSA}$ in $0.005 \mathrm{~mol} / 1 \mathrm{KH}_{2} \mathrm{PO}_{4} / \mathrm{KOH}$ buffer.

\section{Immunobioluminescence assay for gamma-gamma enolase}

Enzymatic activity was measured using a bioluminescence assay described earlier [17]. gamma-gamma Enolase activity was measured after absorption on immobilized anti-gamma antibodies. For each sample $1 \mathrm{mg}(100 \mu \mathrm{l})$ immunobead suspension was used. The reagent was washed with $600 \mu \mathrm{l}$ PBS, after which the pellet was resuspended in $100 \mu 10.1 \mathrm{~mol} / 1 \mathrm{KH}_{2} \mathrm{PO}_{4} / \mathrm{KOH}$ buffer ( $\mathrm{pH}$ 7.2) containing 5 
mmol $/ 1 \mathrm{MgSO}_{4}$. Then $20 \mu \mathrm{l}$ of undiluted serum, plasma or CSF was added. This mixture was incubated for $45 \mathrm{~min}$ at $37^{\circ} \mathrm{C}$. Subsequently the mixture was centrifuged ( $10 \mathrm{~min}, 1000 \times \mathrm{g}$, room temperature), the supernatant was pipetted and the pellet was washed with $600 \mu 1$ PBS. After this the pellet was resuspended in $900 \mu \mathrm{l}$ $0.11 \mathrm{~mol} / \mathrm{l}$ imidazole acetate buffer $(\mathrm{pH} 7.2)$ containing $2.2 \mathrm{mmol} / 1$ EDTA for the measurement of gamma-gamma enolase activity with the bioluminescence assay [17]. Activity was measured in $U / 1(\mu \mathrm{mol}$ substrate converted/min per 1 ; room temperature) using a LKB 1250 luminometer (Wallac, Turku, Finland). The blank value of this assay was $0.13-0.23 \mathrm{U} / 1$, due to contaminating enolase activity of the pyruvate kinase (Boehringer, Mannheim, FRG; No. 128163). The immunobioluminescence assay was compared with the Pharmacia NSE radioimmunoassay. This double antibody radioimmunoassay was carried out according to the instructions of the manufacturer (Pharmacia NSE RIA kit, No. 51-6860-01, Uppsala, Sweden; reference value for serum: $95 \%<12 \mathrm{ng} / \mathrm{ml}$ ).

\section{Results}

\section{The antiserum}

The antiserum appeared to be specific for gamma-enolase subunits as judged by immunodiffusion, immunoelectrophoresis and immunotitration techniques. The antiserum reacted with gamma-gamma enolase as well as with alpha-gamma enolase. No cross-reactivity was observed with alpha-alpha or beta-beta enolase, nor with any other protein present in crude preparations of enolase isoenzymes from human brain and muscle (Fig. 1).

\section{Assay conditions}

Although gamma-gamma enolase is known as the most stable form of the brain enolases [20], enolase activity decreased in some buffers during a $2 \mathrm{~h}$ incubation at $37^{\circ} \mathrm{C}$ as shown in Table I. Based on these results the $0.1 \mathrm{~mol} / 1 \mathrm{KH}_{2} \mathrm{PO}_{4} / \mathrm{KOH}$ buffer containing $5 \mathrm{mmol} / 1 \mathrm{MgSO}_{4}$ was chosen.

The incubation time used in the assay for binding the enzyme to the solid phase was $45 \mathrm{~min}$. The binding of the gamma-gamma enolase to the immunobead reagent was complete after this period for concentrations up to $12 \mathrm{U} / 1$. Activity was fully preserved after binding to the solid phase (Fig. 2: gamma-gamma).

The presence of immunobeads does not influence the photon yield on the detector, as can be demonstrated using the internal ATP standard. A certain amount of ATP gave the same light response in the assay medium with and without immunobeads.

\section{Characteristics of the assay}

Figure 2 shows the results of the application of the solid phase immunobioluminescence assay on partially purified gamma-gamma enolase preparations from human brain. The gamma-gamma enolase activity of the samples was measured directly with the bioluminescence assay [17] ( $x$-axis) and with the immunobioluminescence assay ( $y$-axis). gamma-gamma Enolase activity in the supernatant was 

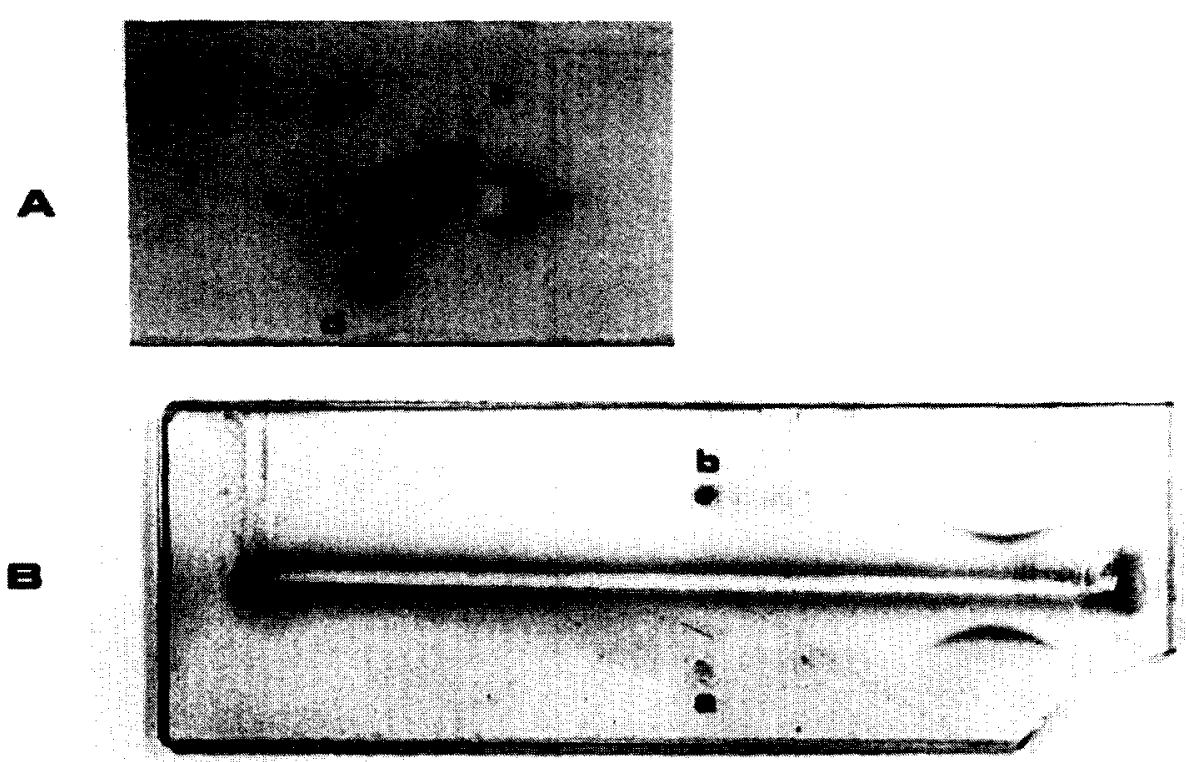

Fig. 1. A. Double immunodiffusion of purified antibody (center well) against: (a) crude preparation brain NSE, (b) completely purified NSE, (c) completely purified brain alpha-alpha enolase), (d) crude muscle extract (beta-beta enolase, (e) crude preparation brain alpha-alpha enolase. B. Electroimmunodiffusion of anti-gamma serum (center slot) against: (a) completely purified NSE and (b) crude preparation NSE. In the crude preparations of brain NSE and alpha-alpha enolase the isoenzymes were separated by DEAE-A50 chromatography as described before [18].

also determined. The original gamma-gamma enolase activity was completely recovered on the beads. The assay is linear to $1012 \mathrm{U} / \mathrm{l}$. At higher concentrations the amount of gamma-gamma enolase in the supernatant increases. The correlation coefficient of the linear part of the figure is 0.9998 .

The within-run coefficient of variation (CV) for a CSF sample with a gammagamma enolase activity of $0.48 \mathrm{U} / 1$ was $2.9 \%(n=6)$. The within-run $\mathrm{CV}$ was $3.1 \%$ for a serum sample containing $1.2 \mathrm{U} / 1$ gamma-gamma enolase $(n=6)$. The between-run CV was measured after reconstitution of lyophilized serum and amounted

\section{TABLE I}

Enolase activity of a partially purified gamma-gamma enolase preparation of $8.5 \mathrm{U} / 1$ in different buffers after incubation at $37^{\circ} \mathrm{C}$ for $2 \mathrm{~h}$

\begin{tabular}{ll}
\hline Buffer & $\begin{array}{l}\text { Residual activity } \\
\text { after incubation }\end{array}$ \\
\hline $0.01 \mathrm{~mol} / 1 \mathrm{KH}_{2} \mathrm{PO}_{4} / \mathrm{KOH} / 0.15 \mathrm{~mol} / 1 \mathrm{NaCl}, \mathrm{pH} 7.2$ (PBS) & $49 \%$ \\
$0.11 \mathrm{~mol} / 1 \mathrm{imidazole}$ acetate $/ 2.2 \mathrm{mmol} / 1 \mathrm{EDTA}, \mathrm{pH} 7.2$ & $4 \%$ \\
$0.1 \mathrm{~mol} / 1 \mathrm{KH}_{2} \mathrm{PO}_{4} / \mathrm{KOH}, \mathrm{pH} 7.2$ & $79 \%$ \\
$0.1 \mathrm{~mol} / 1 \mathrm{KH}_{2} \mathrm{PO}_{4} / \mathrm{KOH} / 5 \mathrm{mmol} / 1 \mathrm{MgSO}_{4}, \mathrm{pH} 7.2(23)$ & $97 \%$ \\
\hline
\end{tabular}


ENOLASE ACTIVITY (U/L)

- on the beads

- in supernatant
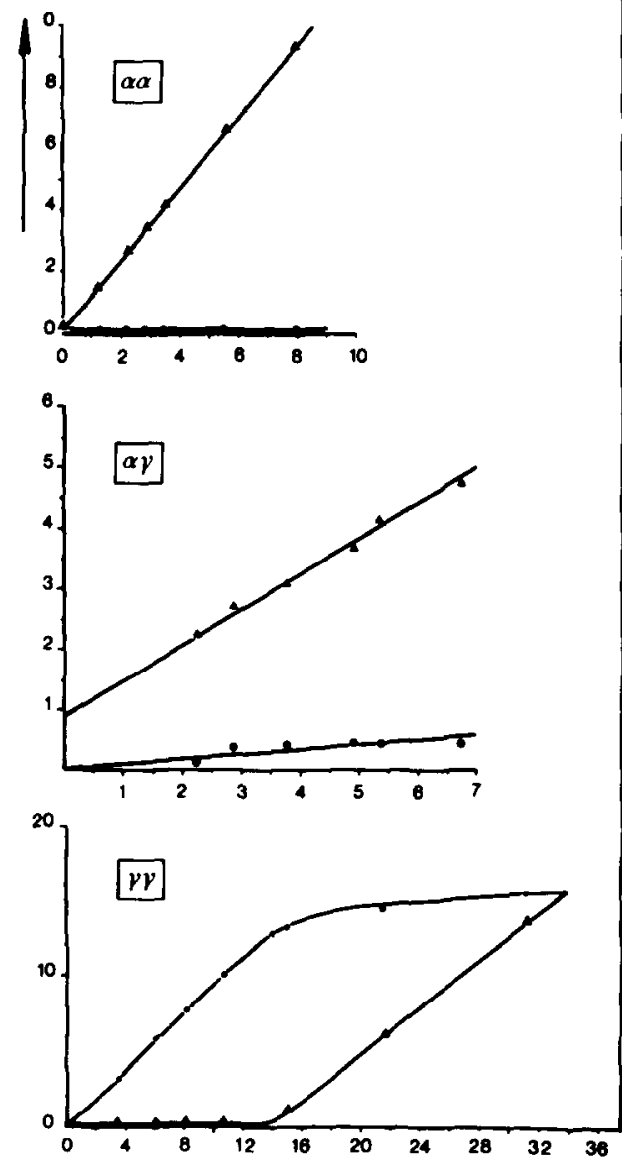

ENOLASE ACTIVITY IN THE SAMPLE (U/L)

Fig. 2. Immunobioluminescence. During the incubation with the beads gamma-gamma enolase binds to the beads while alpha-alpha and alpha-gamma remain in the supernatant. The figure also shows the saturation of the beads with gamma-gamma enolase at higher concentrations.

$6.2 \%(n=7)$. Measurement of samples with low gamma-gamma enolase activity $(<0.20 \mathrm{U} / 1)$ is hampered by the relatively high blank value of the assay. This is not a very serious problem as this activity corresponds with the lower limit of the reference range for CSF and is well below the reference range for blood samples. Moreover only elevated levels of the enzyme are of potential clinical interest.

When immunobeads, without antiserum, were incubated with the different isoenzymes, no nonspecific adsorption directly to the beads was observed. Interfering factors such as haemolysis, turbidity or lipaemia did not influence gamma-gamma enolase activity measurements. 
alpha-alpha Enolase from human brain and beta-beta enolase from human muscle did not bind to the immunobead reagent, as shown in Fig. 2 for purified alpha-alpha enolase. Both isoenzymes were fully recovered in the supernatant. Furthermore, cross-reactivity of maximally $15 \%$ was found for alpha-gamma enolase using the partially purified isoenzyme (activity range $2-8 \mathrm{U} / 1$ ). At all concentrations tested more than $85 \%$ of alpha-gamma activity was found in the supernatant (Fig. 2).

\section{Serum and CSF samples}

gamma-gamma Enolase activity of 9 serum samples from healthy volunteers ranged from 0.73 to $1.3 \mathrm{U} / 1$, corresponding with $8-17 \%$ of total enolase activity [17]. The serum samples all had normal gamma-gamma enolase levels in the radioimmunoassay. The range of gamma-gamma enolase activities of the CSF samples was 0.18 to $0.64 \mathrm{U} / 1$. This was $17-63 \%$ of the total enolase activity, ranging from 0.38 to $3.8 \mathrm{U} / 1$.

The results of the bioluminescence assay were compared with the radioimmunoassay (Fig. 3). There was a good correlation between the two methods for both serum and CSF samples ( $r=0.81$ and 0.86 respectively). The correlation lines for serum and $\mathrm{CSF}$, however, differ considerably. The slope of both lines is significantly different $(0.082$ for serum vs 0.042 for CSF). Both lines have a positive intercept (0.502 and 0.100 respectively).

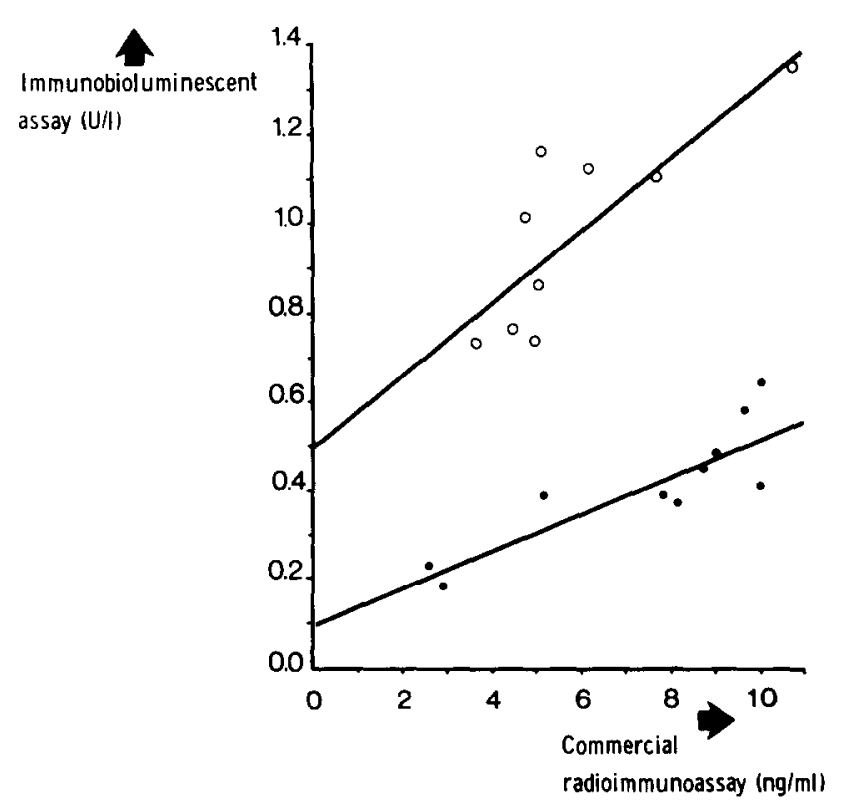

Fig. 3. Comparison of the immunobioluminescence assay with the radioimmunoassay. $\bullet$, CSF samples, O, serum samples. 


\section{Reuse of the immunobead reagent}

Before the immunobead reagent can be re-used, all bound enzyme must be removed without influencing the binding capacity of the antiserum. To test the effectiveness of the recycling procedure, the immunobeads were fully loaded with excess gamma-gamma enolase. After washing with $2 \mathrm{~mol} / 1$ potassium thiocyanate the blank value was $0.21 \mathrm{U} / \mathrm{l}$. This is the normal blank value of the assay. Even after three cycles of loading and unloading, the blank value was not increased. After this procedure the binding capacity was $87 \%$ of the original binding capacity.

\section{Discussion}

The specificity of radioimmunoassays for NSE depends on the specificity of the antibody. The immunobioluminescence assay combines the specificity of the antiserum with the measurement of enzymatic activity thus reaching optimal specificity. In practice there turned out to be no cross-reactivity in the bioluminescence assay with the alpha-alpha and beta-beta isoenzymes.

Figure 2 shows that the original gamma-gamma enolase activity of a sample (less than $12 \mathrm{U} / \mathrm{l}$ ) was completely recovered on the beads. There was no loss of activity by binding of the enzyme to the antiserum. This indicates that there is no inhibition of the active center of the enzyme by the antibody.

The assay is linear until more than ten times the upper limit of normal for CSF samples. Dilution of the sample is not necessary in most cases. Serum samples can be measured directly as well. The assay is linear to approximately three times the upper limit of normal for serum samples. As the immunobcads can be prepared in advance it takes less than an hour to obtain a result. The immunobeads can be reused several times without serious loss of binding capacity and without decline in sensitivity. The reproducibility of the assay, both within and between assays, is better than for the radioimmunoassay (RIA data on reproducibility, Cooper et al. [21]). Although the correlation between both methods is good, it was surprising to find different correlation lines for serum and for CSF (Fig. 3). While similar amounts of NSE were found in serum and CSF with the radioimmunoassay, the immunobiolumineseence results indicated a two- to four-fold higher gamma-gamma enolase activity in serum compared with CSF. Several possible explanations can be given for this observation. 1. A difference in cross-reactivity of the alpha-gamma isoenzyme in both assays. CSF is known to contain relatively more alpha-gamma enolase than serum. 2. The presence of a substantial amount of inactive gammagamma enolase in CSF. 3. A non-enolase protein cross-reacting in the RIA. The present data do not allow any further conclusions.

Immunobioluminescence methods have been used both by Gerbitz [15] and Viallard [16] for the detection of NSE in human plasma or serum. The sensitivity of our assay, using the same basic principle allows direct measurement of gammagamma enolase in unconcentrated CSF. An advantage over the method described by Viallard is that only a single determination is required to obtain the result, thus avoiding the subtraction of alpha-alpha enolase from total enolase activity. 
Both Gerbitz and Viallard have described lower activities for NSE in blood of adult healthy volunteers than found in the present study $[15,16]$. This can be explained by different assay conditions in our study. This includes the addition of $\mathrm{N}$-acetylcysteine which has not been used by the other authors. This addition results in a mean increase of $28 \%$ in total enolase activity in blood (data not shown). The effect on gamma-gamma enolase activity could even be higher. Other potentially contributing factors are differences in $\mathrm{pH}$, buffer strength, EDTA, albumin, $\mathrm{Mg}$, ADP or AP5A concentration between the studies. Furthermore the study of Gerbitz has used plasma. As this leads to lower activity levels than for serum the results of both studies are difficult to compare.

This study was not designed as a clinical study. No diagnostic information on the neurological patients has been included. In 10 CSF samples we found a wide variation in the contribution of gamma-gamma enolase to the total enolase enzymatic activity (17-63\%). Future clinical studies will provide reliable reference values for CSF samples and can provide insight in the indications for the neurologist to request this determination in CSF.

\section{Acknowledgements}

The authors wish to thank Mrs. G. Schipper-Kester and Mrs. L.M.J. van Woerkom for technical assistance. This study was in part supported by a grant from Merck, Darmstadt, FRG.

\section{References}

1 Schmechel D, Marangos PJ, Brightman M. Neuron-specific enolase is a molecular marker for peripheral and central neuruendocrine cells. Nature 1978;276:834-836.

2 Schmechel DE, Marangos PJ, Zis AP, et al. Brain enolases as specific markers of neuronal and glial cells. Science 1978;199:313-315.

3 Hay E, Royds JA, Davies-Jones GAB, et al. Cerebrospinal fluid enolase in stroke. $J$ Neurol Neurosurg Psychiatry 1984;47:724-729.

4 Scarna H, Delafosse B, Steinberg R, et al. Neuron-specific enolase as a marker of neuronal lesions during various comas in man. Neurochem Intern 1982;4:405-411.

5 Dauberschmidt R, Marangos PJ, Zinsmeyer J, et al. Severe head trauma and the changes of concentration of neuron-specific enolase in plasma and in cerebrospinal fluid. Clin Chim Acta $1983 ; 131: 165-170$.

6 Tapia FJ, Polak JM, Barbosa AJA, et al. Neuron-specific enolase is produced by neuroendocrine tumours. Lancet 1981;1:808-811.

7 Dhillon AP, Rode J, Leathem A. Neuron specific enolase; an aid to the diagnosis of melanoma and neuroblastoma. Histopathology 1982;6:81-92.

8 Nakajima T, Kameya T, Tsumuraya M, et al. Enolase distribution in human brain tumors, retinoblastomas and pituitary adenomas. Brain Res 1984;308:215-222.

9 Prinz RA, Marangos PJ. Serum neuron-specific enolase: a marker for nonfunctioning pancreatic islet cell carcinoma. Am J Surg 1983;145:77-80.

10 Oskam R, Rijksen G, Lips CJM, et al. Enolase isozymes in differentiated and undifferentiated medullary thyroid carcinomas. Cancer 1985;55:394 399.

11 Zeltzer PM, Parma AM, Dalton A, et al. Raised neuron-specific enolase in serum of children with metastatic neuroblastoma. Lancet 1983;1:361-363. 
12 Carney DN, Marangos PJ, Ihde DC, et al. Serum neuron-specific enolase: a marker for disease extent and response to therapy of small-cell lung cancer. Lancet 1982;1:583-585.

13 Kato K, Suzuki F, Semba R. Determination of brain enolase isozymes with an enzyme immunoassay at the level of single neurons. J Neurochem 1981;37:998-1005.

14 Parma AM, Marangos PJ, Goodwin FK. A more sensitive radioimmunoassay for neuron-specific enolase suitable for cerebrospinal fluid determinations. J Neurochem 1981;36:1093-1097.

15 Gerbitz KD, Summer J, Thallemer J. Brain-specific proteins: solid phase immunobioluminescent assay for neuron-specific enolase in human plasma. Clin Chem 1984;30:382-386.

16 Viallard JL, Van Murthy MR, Betail G and Dastugue B. Determination of serum neuron-specific enolase by differential immunocapture. Clin. Chim. Acta 1986;161:1-10.

17 Wevers RA, Jacobs AAC, Hommes OR. A bioluminescent assay for enolase (EC 4.2.1.11) activity in human serum and cerebrospinal fluid. Clin Chim Acta 1983;135:159-168.

18 Van den Doel EMH, Rijksen G, Roholl PJM et al. Enolase isoenzymes in human gliomas. J Neurosurg 1986;65:345-353.

19 Taylor CB, Royds JA, Timperley WR. Neuron-specific enolase as a marker for neuroendocrine tumors. In: Markers of human ectodermal tumors. Editors: Staal GEJ and van Veelen CWM. CRC Press 1986, 119-154.

20 Marangos PJ, Parma AM, Goodwin FK. Functional properties of neuronal and glial isoenzymes of brain enolase. J Neurochem 1978;31:727-732.

21 Cooper F.H, Splinter TAW, Brown DA et al. Evaluation of radioimmunoassay for neuron specific enolase in small cell lung cancer. Br J Cancer 1985;52:333-338.

22 Pahlman S, Esscher T, Bergvall P, Odelstad L. Purification and characterization of human neuronspecific enolase: radioimmunoassay development. Tumour Biology 1984;5:127-139. 